\title{
Correction to: Prediction of grout take using rock mass properties
}

\author{
A. Rastegarnia ${ }^{1}$ - G. R. Lashkaripour $^{1} \cdot$ M. Ghafoori $^{1}$ \\ Published online: 13 June 2019 \\ (C) Springer-Verlag GmbH Germany, part of Springer Nature 2019
}

Correction to: Bull Eng Geol Environ (2017) 76:1643-1654 https://doi.org/10.1007/s10064-016-0956-5

The article was originally published with incorrect capturing of author name. The name of the first author A. Rastegar Nia was incorrect. His name has now been corrected as A. Rastegarnia. The correct name is presented here.

The online version of the original article can be found at https://doi.org/ 10.1007/s10064-016-0956-5

G. R. Lashkaripour

lashkaripour@um.ac.ir

1 Department of Geology, Faculty of Science, Ferdowsi University of Mashhad, Mashhad 9177948974, Iran 